\title{
Joint Guideline of the OEGGG, AGO, AGK and ÖGZ on the Diagnosis and Treatment of Cervical Intraepithelial Neoplasia and Appropriate Procedures When Cytological Specimens Are Unsatisfactory
} Gemeinsame Leitlinie der OEGGG, AGO, AGK und ÖGZ zur Diagnose und Therapie von zervikalen intraepithelialen Neoplasien sowie Vorgangsweise bei zytologischen Befunden mit eingeschränkter Qualität

\section{(ㄷ) (1) (오 $\ominus$}

Authors

Olaf Reich ${ }^{1,7}$, Georg Braune ${ }^{6}$, Wolfgang Eppel ${ }^{2}$, Thomas Fiedler ${ }^{6}$, Anton Graf ${ }^{7}$, Lukas Hefler ${ }^{3,8}$, Elmar Joura ${ }^{2,7}$, Heinz Kölb|' ${ }^{2,6}$, Christian Marth ${ }^{4,8}$, Wolfgang Pokieser ${ }^{9}$, Peter Regitnig ${ }^{5,9}$, Alexander Reinthaller ${ }^{2,8}$, Karl Tamussino ${ }^{1,6}$, Andreas Widschwendter ${ }^{4,7}$, Alain Zeimet ${ }^{4,8}$, Petra Kohlberger ${ }^{2,6}$

Affiliations

1 Universitätsklinik für Frauenheilkunde und Geburtshilfe, Medizinische Universität Graz, Graz, Austria

2 Universitätsklinik für Frauenheilkunde, Medizinische Universität Wien, Wien, Austria

3 Ordensklinikum Linz, Linz, Austria

4 Universitätsklinik für Gynäkologie und Geburtshilfe, Medizinische Universität Innsbruck, Innsbruck, Austria

5 Institut für Pathologie, Medizinische Universität Graz, Graz, Austria

6 Österreichische Gesellschaft für Gynäkologie und Geburtshilfe (OEGGG)

7 Arbeitsgemeinschaft für Kolposkopie (AGK)

8 Arbeitsgemeinschaft Gynäkologische Onkologie der OEGGG (AGO)

9 Österreichische Gesellschaft für Zytologie (ÖGZ)

Key words

cervical intraepithelial neoplasia, cytology, colposcopy

Schlüsselwörter

zervikale intraepitheliale Neoplasie, Zytologie, Kolposkopie

received 27.9.2018

accepted $\quad 15.10 .2018$

Bibliography

DOI https://doi.org/10.1055/a-0764-4875

Geburtsh Frauenheilk 2018; 78: 1232-1244 @ Georg Thieme

Verlag KG Stuttgart · New York | ISSN 0016-5751
Correspondence

a.o. Univ. Prof. Dr. Petra Kohlberger, M. Sc. Universitätsklinik für Frauenheilkunde,

Medizinische Universität Wien

Währinger Gürtel 18-20, A-1090 Wien, Österreich

petra.kohlberger@meduniwien.ac.at

Deutsche Version unter:

https://doi.org/10.1055/a-0764-4875

\section{ABSTRACT}

Purpose On January 1st, 2018, the ÖGZ (Austrian Society of Cytology) revised its cytological nomenclature to make it more similar to the 2015 Bethesda system. Following these changes, the Austrian Society of Gynecology and Obstetrics felt it necessary to revise the approach currently used in Austria to diagnose and treat CIN and to review the procedures to be followed when the quality of cytological specimens is unsatisfactory. It was not possible to adopt the German S3 guideline "Prevention of Cervical Cancer" in its entirety, because the Munich III gynecological cytology nomenclature used in Germany is not used in Austria. This made it necessary to compile a separate scientific opinion for Austria.

Methodology The OEGGG worked together with the ÖGZ (Austrian Society for Cytology), AGO Austria (Austrian Working Group for Gynecological Oncology), the AGK (Colposcopy Working Group), and physicians representing gynecologists in private practice. The different scientific associations nominated representatives, who attended the various meetings. After an in-depth analysis of the recent literature, three meetings and numerous votes by telephone, we were able to achieve a consensus about the contents of this guideline.

Recommendations The guideline provides recommendations for the diagnosis and treatment of CIN which take ac- 
count of the gynecological cytology nomenclature used in Austria.

\section{ZUSAMMENFASSUNG}

Ziel Die ÖGZ (Österreichische Gesellschaft für Zytologie) hat zum 1.1.2018 die zytologische Nomenklatur überarbeitet und an die Bethesda-2015-Nomenklatur angelehnt. Daher war es notwendig, seitens der österreichischen Fachgesellschaft eine Überarbeitung der bis jetzt in Österreich gültigen Vorgehensweise zur Diagnose und Therapie von CIN sowie Vorgehensweise bei zytologischen Befunden mit eingeschränkter Qualität zu veranlassen. Eine komplette Übernahme der S3-Leitlinie „Prävention des Zervixkarzinoms“ ist aufgrund der in Deutschland geltenden München-III-Nomenklatur der gynäkologischen Zytologie für Österreich nicht möglich und daher ergab sich die Notwendigkeit des Verfassens einer eigenen wissenschaftlichen Stellungnahme für Österreich.
Methodik Die OEGGG hat die Zusammenarbeit sowohl mit der ÖGZ (Österreichische Gesellschaft für Zytologie), der AGO Austria (Arbeitsgemeinschaft Gynäkologische Onkologie Österreich), der AGK (Arbeitsgemeinschaft Kolposkopie) als auch mit repräsentativen Vertretern der niedergelassenen Frauenärzten gesucht. Von den jeweiligen Fachgesellschaften wurden repräsentative Vertreter für die Sitzungsteilnahme benannt. Nach eingehender Analyse der aktuellen Literatur und insgesamt 3 Sitzungen mit zahlreichen fernmündlichen $A b$ stimmungen ist es uns gelungen, einen Konsens der Inhalte zu erarbeiten.

Empfehlungen Es werden Empfehlungen zur Diagnose und Therapie der CIN gegeben unter Berücksichtigung der in Österreich geltenden Gynäkologische-Zytologie-Nomenklatur.

\section{Introduction}

This guideline describes the approach currently recommended in Austria for the work-up of abnormal cytological findings and positive HPV test results, the recommended treatment for squamous (SIL, CIN) and glandular (AIS) cervical intraepithelial neoplasia and the procedures to be followed when cytological specimens are unsatisfactory.

Abnormal findings can occur during primary cytological screening and in the context of primary HPV-based screening for cervical cancer with cytological triage. Within the currently existing opportunistic screening program for cervical cancer we recommend that women aged 30 years and above undergo validated testing for HPV at least every 3 years. This recommendation applies both to HPV-vaccinated and non-HPV-vaccinated women. Routine co-testing should be avoided; the procedures can be carried out alternately ([19, 24]; cf. also 3.4).

This guideline aims to harmonize and standardize management and avoid under- and over-treatment. A work-up based on the recommendations of this guideline will reduce the number of conizations and prevent delays in diagnosis. Women with cytological abnormalities and with persistent oncogenic HPV infections require a careful diagnostic work-up and a colposcopy examination. While there are several options for borderline and low-grade lesions, high-grade cytological lesions should be investigated immediately. Simply repeating the cytological smear without a colposcopy and without ascertaining the patient's HPV status (for patients aged $>30$ years) is not recommended. According to the Austrian Vaccination Schedule, HPV vaccination is recommended for all women up to the age of 45 years. Primary testing for HPV is preferred in HPV-vaccinated women aged 30 years and above [10]. Any deviations from the recommendations given in this guideline must be justified and recorded for forensic purposes.

The histological terminology used in this guideline corresponds to the current histological WHO 2014 classification [13] and its German-language version [23]. When examining women who wish to have children, it is important that the pathologist re- porting the findings differentiates HSIL (CIN II) from HSIL (CIN III) as careful differentiation will allow the treating physician to wait and see whether any regression of the CIN II occurs which could help to avoid obstetric complications subsequent to conization [26].

The colposcopic terminology corresponds to the Rio de Janeiro 2011 nomenclature of the International Federation of Cervical Pathology and Colposcopy (IFCPC) [4] and its approved German-language version $[6,20]$.

Cytological findings are recorded in accordance with the guidelines of the Austrian Society for Cytology (ÖGZ) on the nomenclature and reporting of cervical cytology findings [21].

\section{Methodology}

Statements and recommendations were voted on at three consensus conferences $[3,17]$. The statements and recommendations were discussed at the consensus conferences, which were held in Vienna on 30 January 2018, 14 March 2018 and 20 June 2018, and participants agreed to proposals during the final moderated session. The compilation of this scientific opinion also took the previous recommendations (compiled in 2015) and the recommendations of the German S3 Guideline on the Prevention of Cervical Cancer [24] into special consideration.

During the consensus process, participants who were present voted on the wording of the scientific opinion during the sessions, while participants who had been excused from attending voted by telephone. As no systematic search, selection, evaluation and synthesis of evidence was carried out, no level of evidence is provided for the recommendations and statements.

\section{Diagnosis}

The following examination procedure is recommended to determine whether any dysplastic changes of the cervix uteri are present. 


\subsection{Inspection and colposcopy}

Unaided visual inspection after cleaning of the cervix uteri; targeted cytological smear (great care must be taken to ensure that a smear is obtained from the transformation zone!); a smear specimen may be taken to test for HPV; acetic acid test (3-5\% acetic acid); Schiller's iodine test may be used. Findings must be recorded (in writing, using a drawing, possibly even photographed or videoed).

\subsection{Conventional cytology}

Smear samples should be obtained from the ectocervix and endocervix (transformation zone) using suitable sampling tools (spatula and/or brush). The sample must be spread thinly and evenly, usually on a slide, and immediately fixed using a suitable spray, or the sample can be placed in $96 \%$ alcohol for at least 10 minutes. Alternatively, thin-layer cytology can be used to obtain a sample.

\subsection{Histological specimens}

Tissue sampling can be done either by:

- punch biopsy with samples taken from the area of maximum changes using biopsy forceps during colposcopy performed to visualize the area (take several biopsies if necessary) [28].

- endocervical curettage (if there is a suspicion of endocervical involvement); pregnant patients should not undergo endocervical curettage.

\subsection{Testing for HPV}

Persistent infection with high-risk human papillomavirus (highrisk HPV) is a prerequisite for developing cervical cancer or its precursors $[5,27]$. The only exceptions are a few rare cervical adenocarcinoma subtypes [8]. A latency period of several years is assumed to exist between initial HPV infection and the development of invasive carcinoma. This means that a negative high-risk HPV test has a high negative predictive value; the existence of cervical dysplasia requiring treatment over the longer term can be largely excluded. Subtype-specific HPV tests (for HPV type 16 and type 18) provide additional predictive and prognostic information.
Testing for low-risk HPV subtypes (low-risk HPV) provides no additional relevant Information and should therefore not be carried out.

\subsubsection{Methods for diagnosing high-risk HPV}

Many different tests to detect high-risk HPV are used all over the world. As the HPV tests used in Europe are currently not subjected to standard quality controls, it is important to only use tests in routine clinical practice which comply with the internationally accepted criteria of Meijer and Stoler [1, 15, 25]. The following tests currently fulfil these quality criteria: Digene Hybrid Capture 2 High-Risk HPV DNA Test ${ }^{\circledR}$ (QIAGEN); Cobas HPV Test ${ }^{\circledR}$ (Roche); Cervista ${ }^{\circledR}$ HPV HR (Hologic); APTIMA HPV Assay ${ }^{\circledR}$ (Hologic) Papillocheck $^{\circledR}$ (Greiner Bio One); Abbott RT High-risk HPV Test ${ }^{\circledR}$ (Abbott); BD Onclarity HPV Test ${ }^{\circledR}$ (BD) [24].

\section{Management of Abnormal Cytological Findings and Positive HPV Test}

\subsection{Management following positive HPV test ( Fig. 1)}

Colposcopy and cytological follow-up examinations should be carried out within 6 months at the latest [24].

\subsection{Management of patients with PAP III (ASCUS, ASC-H) ( Fig. 2)}

HPV testing is recommended in Austria as the primary work-up for PAP III. Patients proven to have high-risk HPV infection should have a colposcopy and histological evaluation without delay.

Patients with PAP III but no evidence of high-risk HPV infection should undergo further evaluation for other possible causes.

Women with Pap III and existing inflammation and/or atrophy can be given a short course of estrogen and/or treated for vaginitis before repeating the cytology test and the histological evaluation.

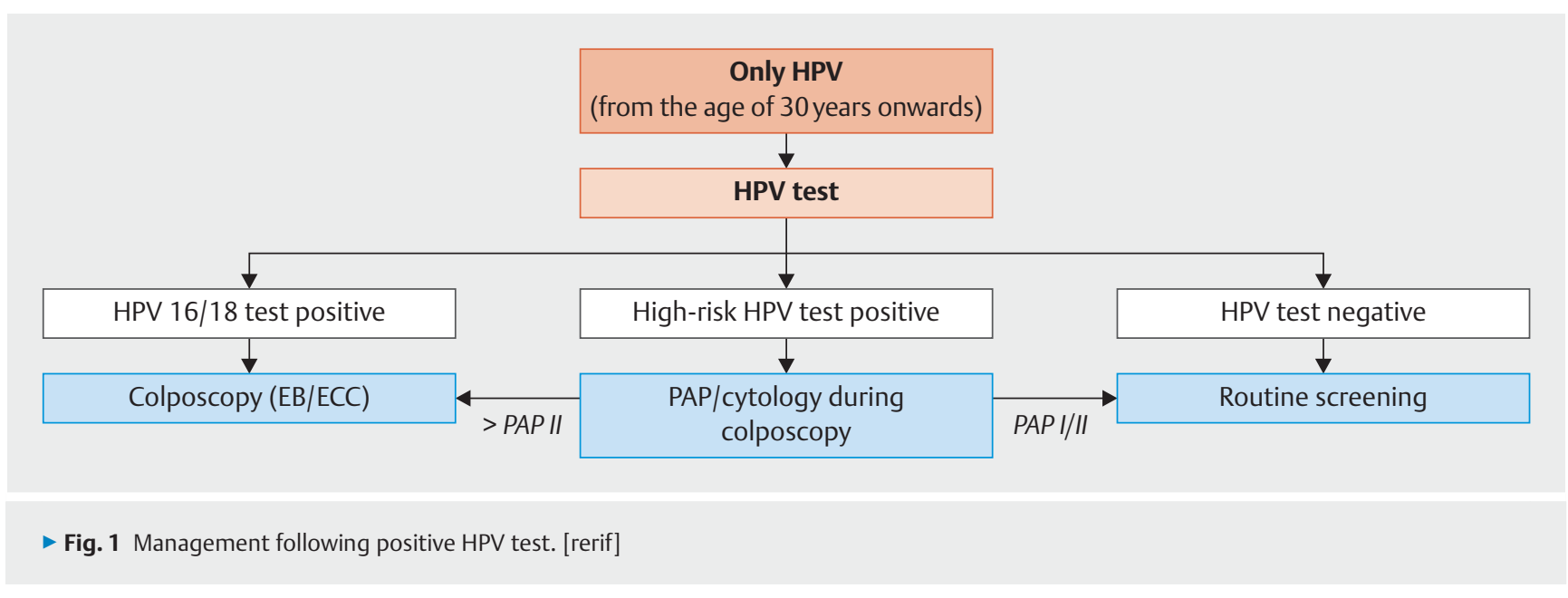




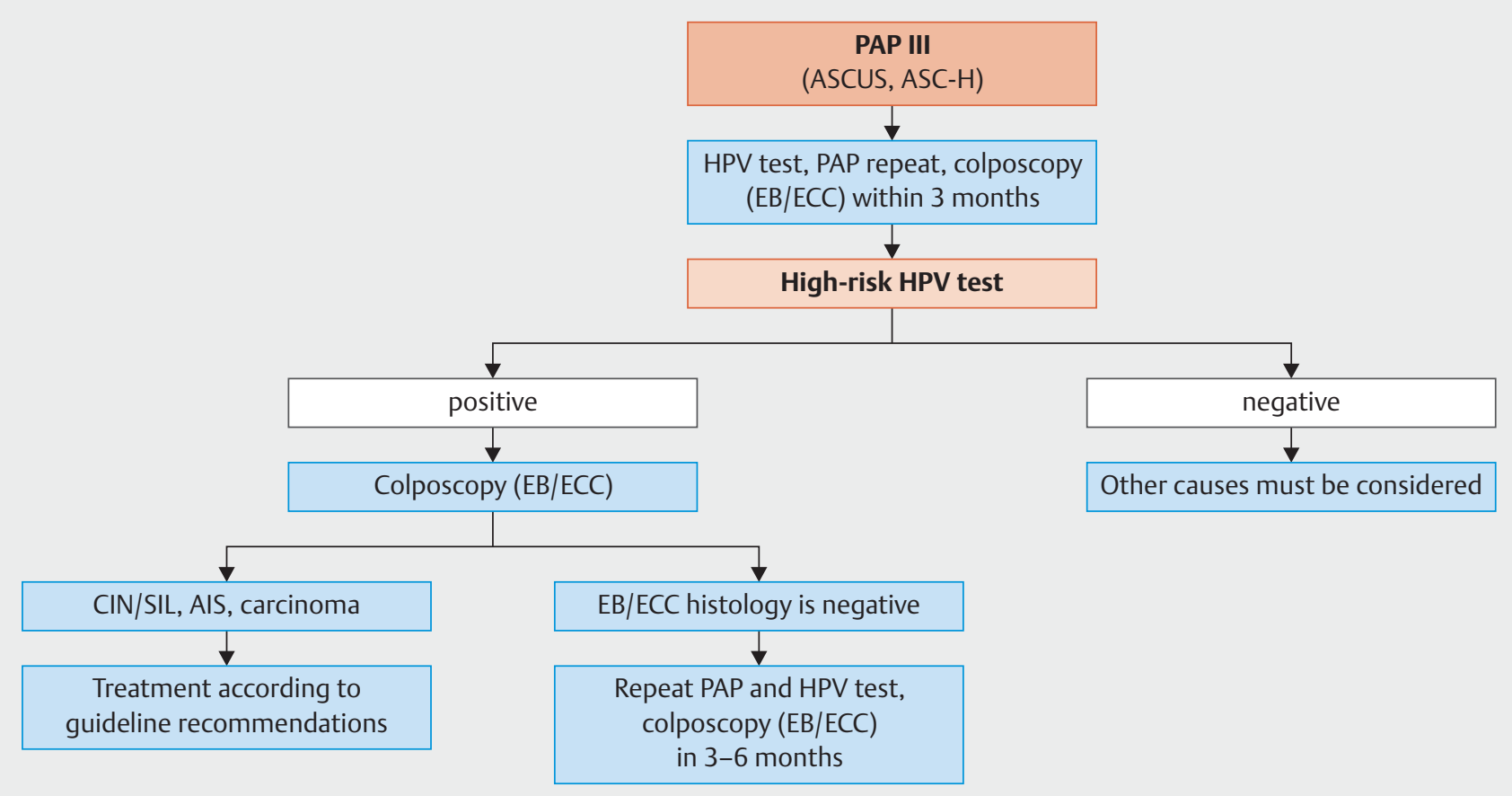

- Fig. 2 Management of patients with PAP III (ASCUS, ASC-H). [rerif]

\subsection{Management of patients with PAP IIID (LSIL) ( $\vee$ Fig. 3)}

The detection of high-risk HPV has a higher sensitivity for HSIL+ (CIN III+) than repeat cytology [24].

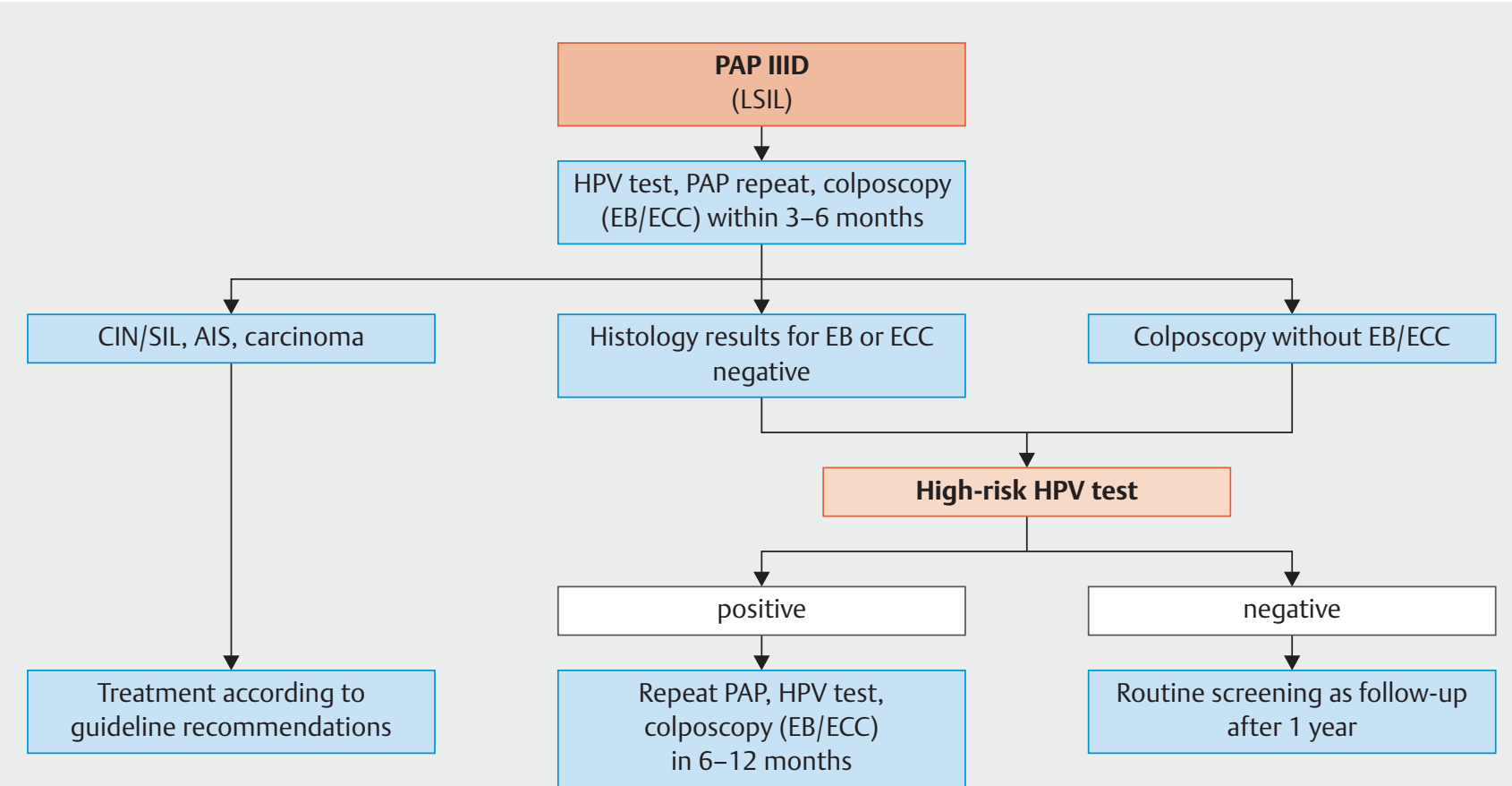

> Fig. 3 Management of patients with PAP IIID (LSIL). [rerif] 


\subsection{Management of patients with PAP IIIG (AGC-NOS, AGC) ( $\vee$ Fig. 4 )}

If histological findings of women with PAP IIIG and positive for high-risk HPV are negative, they should be referred for diagnostic conization as soon as possible.

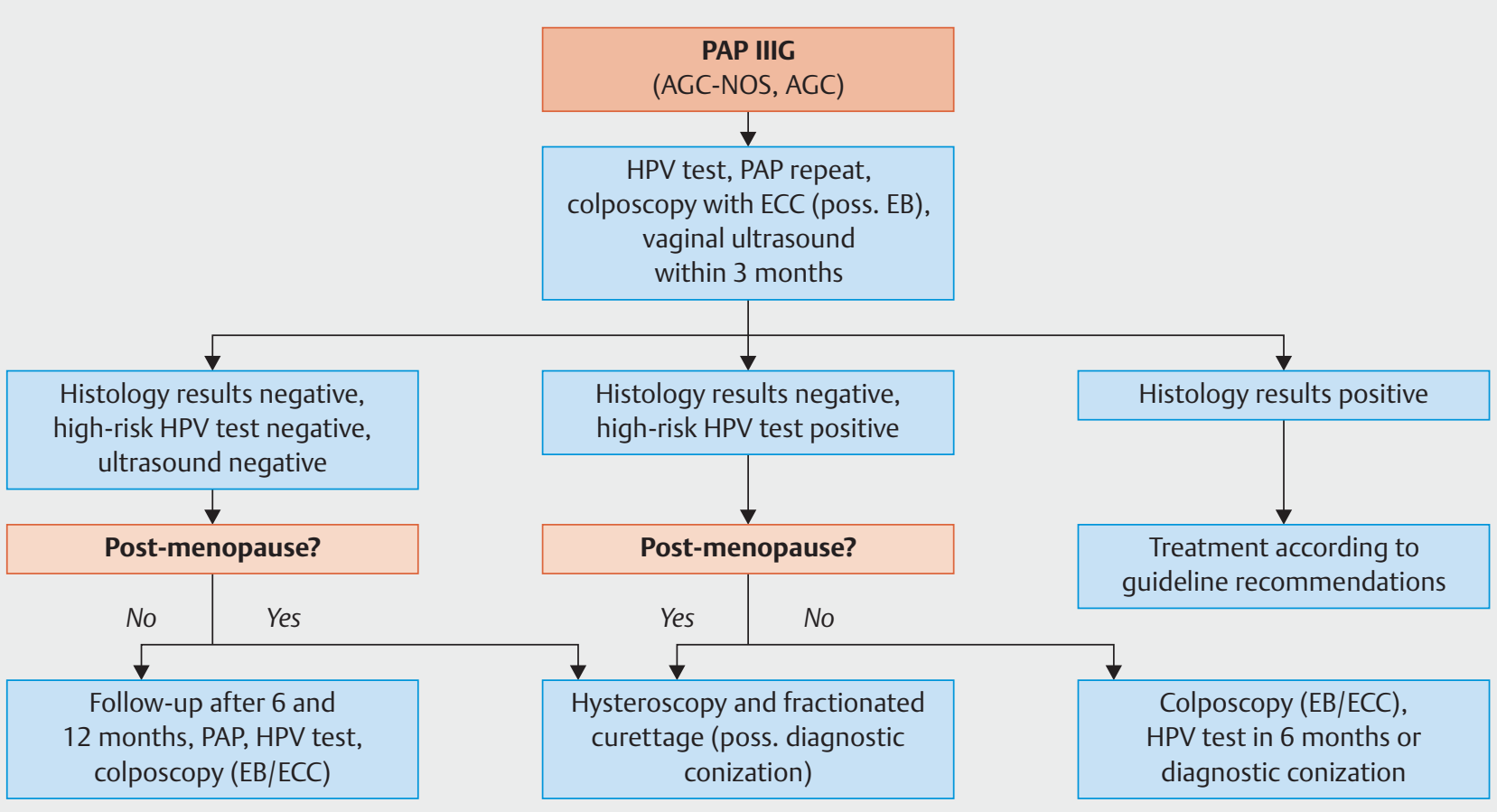

Fig. 4 Management of patients with PAP IIIG (AGC-NOS, AGC). [rerif]

\subsection{Management of patients with PAP IV (HSIL, AIS) ( Fig. 5)}

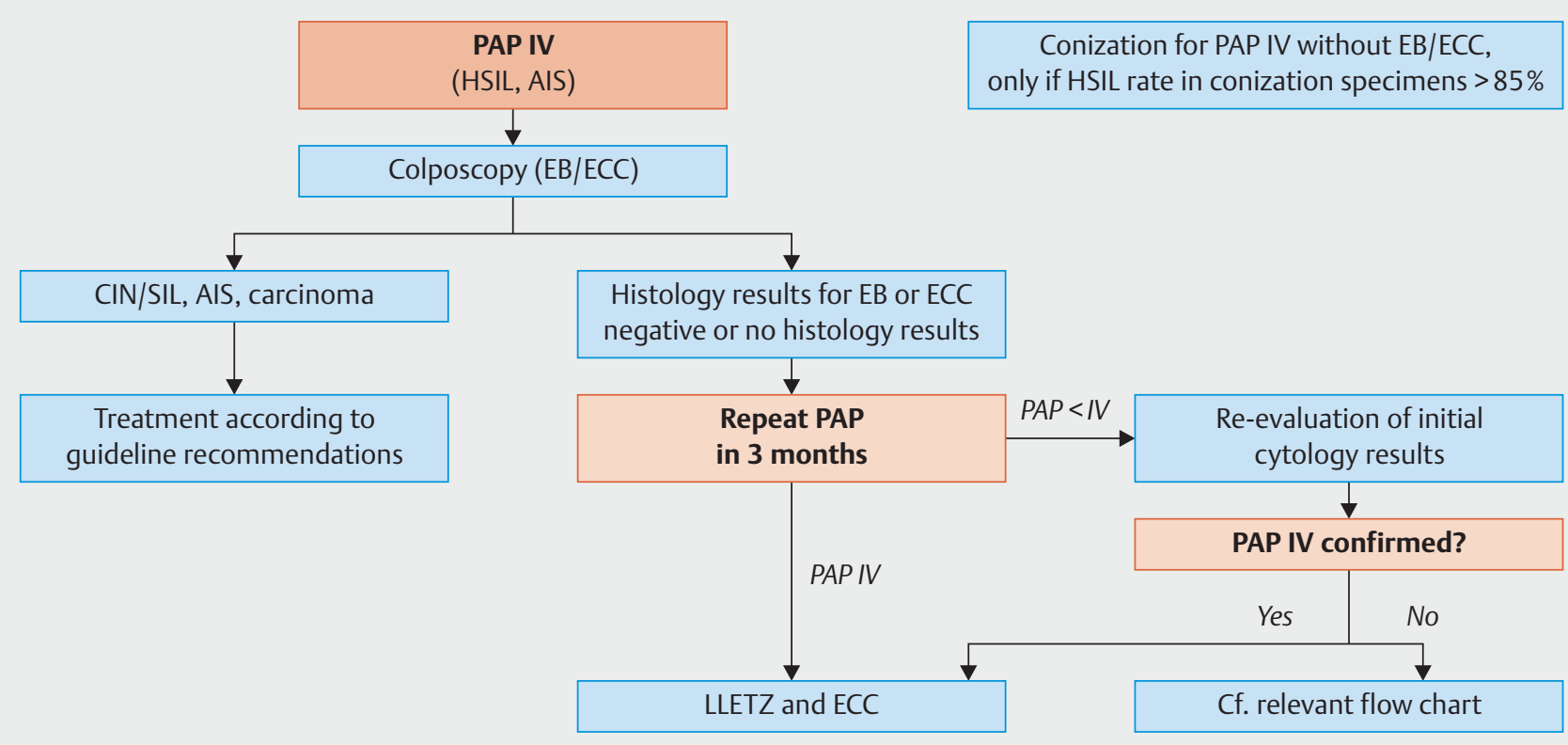

Fig. 5 Management of patients with PAP IV (HSIL, AIS). [rerif] 


\subsection{Management of patients with PAP V $(\triangleright$ Fig. 6$)$}

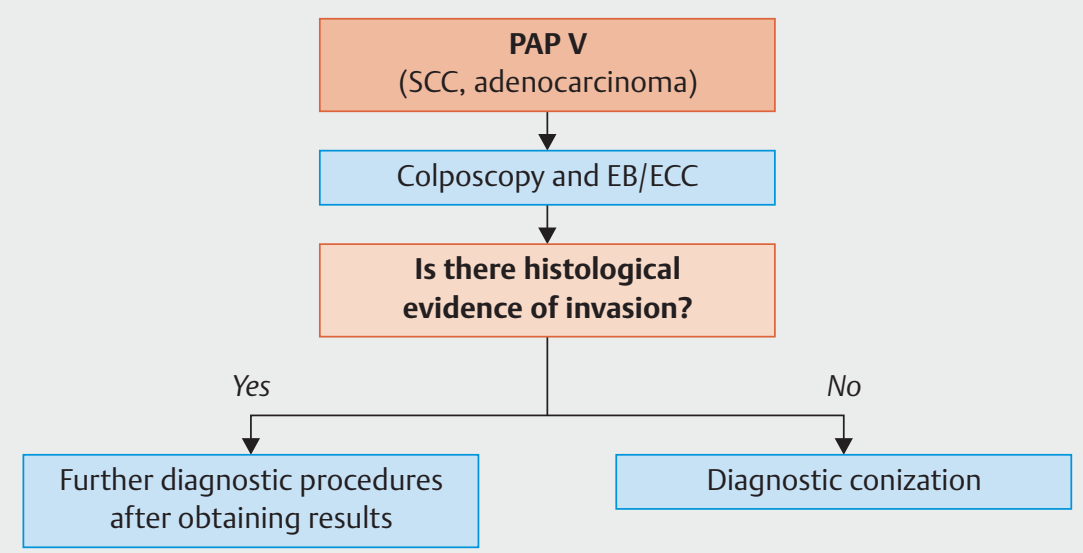

D Fig. 6 Management of patients with PAP V. [rerif]

In accordance with internationally accepted quality standards, a colposcopy should be done prior to carrying out conization or destruction of superficial tissue [16].

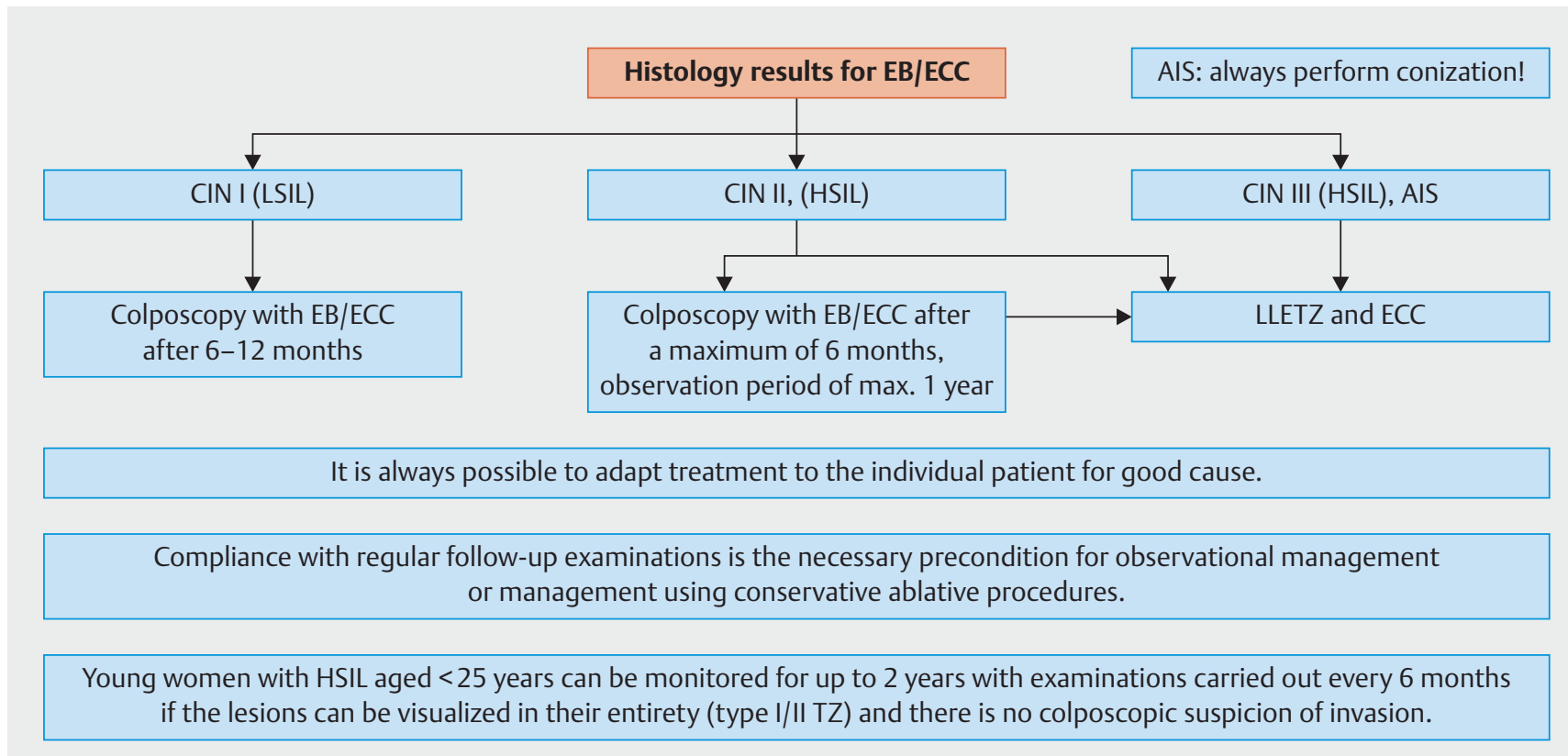

- Fig. 7 Procedure after histological verification of LSIL (CIN I), HSIL (CIN II, CIN III), AIS. [rerif] 


\subsection{Resection}

Indications:

- Persistent CIN I (LSIL) for more than 2 years

- Persistent high-risk HPV infection for more than 2 years with additional indications (divergent findings) [12]

- HSIL (CIN II, III)

- Recurrent pathological cytology without a histological correlate

- Suspicion of early invasion

- Suspicion of AIS

Note: Contrary to the approach used in the USA, in Austria as in other European countries, CIN II are not classified as HSILs which require immediate treatment [24].

Technique:

- Conization using high-frequency loop (loop conization, LEEP, loop excision, loop cone biopsy; LLETZ) is recommended. Because of potential obstetric complications [14] the aim must be to achieve resection with narrow tumor-free margins. Once the patient no longer wishes to have children, the radical excision can be expanded and a larger cone can be resected.

\subsection{Superficial destruction}

Possible indications:

- LSIL (condylomas, CIN I)

Requirements:

- Ectocervical location of lesion

- Transformation zone can be visualized in its entirety

- Previous biopsy

- Colposcopy and cytology must be carried out after 6 months to monitor the site.

\subsection{Additional procedures after conization}

There is some evidence in the literature that HPV vaccination after conization reduces the risk of recurrence $[9,11]$. Indicators of therapy failure include persistent HPV, positive resection margins, older patient age, large lesions, small excision specimen and limited experience of the surgeon [2].

Prospective observational studies have shown that detection of high-risk HPV is the most sensitive method indicating residual or recurrent lesions [2]. Testing for high-risk HPV should be carried out 6 months after treatment at the earliest.

Resection of HSIL (CIN II, III) with tumor-free margins

Gynecological examinations (colposcopy, cytology) should be carried out at regular intervals to monitor changes.

Testing for high-risk HPV should be carried out 6 months after treatment. If the test results are positive but the results of cytology, histology and colposcopy are unremarkable, a repeat test for high-risk HPV should be carried out after a further 6 months. Women with a negative high-risk HPV test results can be followed up with routine screening performed at regular intervals [7, 24].

Resection of HSIL (CIN II, CIN III) without tumor-free margins

Resection of an HSIL without tumor-free margins does not require immediate reconizaton/hysterectomy [22,24]. Follow-up colposcopy, cytology and histology examinations should be carried out after 3-6 months, although testing for HPV should only be carried out after 6 months. Reconizaton/hysterectomy should only be carried out for persistent HSIL.

\section{Resection of AIS without tumor-free margins}

It should be noted that if an AIS is resected without achieving tumor-free margins, a second resection (or a hysterectomy, if indicated) must be carried out in all cases [24].

Currently, opinions differ internationally with regard to evaluating the evidence for superficial destruction.

PAP cannot be adequately assessed (no endocervical cells): control examination post partum
Patient is pregnant

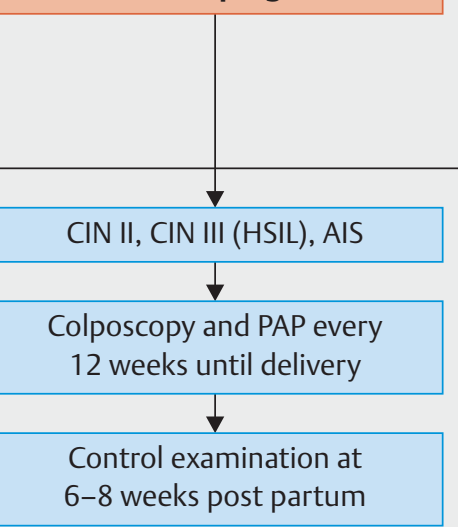

PAP evaluation can be performed the same way as in non-pregnant women, however no ECC in pregnant women!!

Control examination at 6-8 weeks post partum

- Fig. 8 CIN (SIL) in Pregnancy. [rerif] 


\subsection{Diagnosis}

- Colposcopy

- Cytology

- Histological evaluation if there is a suspicion of invasion

A biopsy can be carried out safely during pregnancy and should be performed if colposcopy results are unclear and there is a suspicion of invasion. Endocervical curettage is contra-indicated in pregnancy.

\subsection{Treatment}

Surgical treatment in pregnancy should be reserved for exceptional cases; it should only be done if there is a very high suspicion of invasion and it should only be carried out in specialized centers.

\section{$7 \quad$ Nomenclature and Reporting of Cytological Findings}

The contents of this chapter represent a summary of the quality standards/recommendations for gynecological cervical cytology of the ÖGZ (ÖGPath, 2nd revised version of July 2017).

\subsection{Additional information provided on the cytological request form}

The additional information provided must include:

- patient data (name, maiden name, first name, date of birth, insurance number, name of the patient's medical insurance company),

- date of cytology examination,

- name of sender (and of the treating physician, if not identical with sender),

- data about the specimen (type of specimen, site where sampled, device used for sampling),

- clinical questions and important clinical data such as information about any history of bleeding, information about the patient's hormonal status (for example, hormone substitution, ovulation inhibitors, pregnancy, lactation, menopause), colposcopy findings (e.g., inflammation, polyps), abnormal gynecological bleeding, any intrauterine pessaries, previous gynecological or other relevant operations (e.g., conization, hysterectomy), relevant treatment (irradiation, chemotherapy, cytostatic drugs), HPV status, previous pathological cervical cytology findings.

\subsection{Assessment of smear adequacy}

Assessed smears should be classified into one of the following three groups. The criteria for unsatisfactory smear quality are defined as follows, based on the corresponding criteria of the Bethesda system:
A) Quality of smear: "Can be assessed without difficulty and is representative"

B) Quality of smear: "Unsatisfactory because..."

C) Quality of smear: "Cannot be assessed" (= Pap 0)

1. Not processed due to technical and/or administrative deficiencies

2. Processed but could not be evaluated because...

A) Quality of smear: "Can be assessed without difficulty and is representative" (all of the listed criteria must be met):

- Pap smear labeled appropriately for identification purposes

- Sufficient clinical information is provided

- Criteria for representativity, method and technical processing:

- Adequate number of cells: conventional smear should include between 8000 and 12000 cells, thin-layer specimen should include a minimum of 5000 well preserved and clearly visible squamous epithelial cells (for instructions and test images to estimate the number of cells present, cf. The Bethesda System, 3rd edition, page 3 et seq. for thin-layer smears and page 11 et seq. for conventional smears, or https://bethesda.soc.wisc.edu/) [18]. Determining cell contents using the coated surface of the slide is no longer considered adequate.

- Columnar epithelial cells and/or metaplastic cells in patients with ectocervix. Minimum number: at least 10 well preserved endocervical cells and/or metaplastic squamous epithelial cells, present either as individual cells or in groups.

Note: The Bethesda System no longer assumes that insufficient numbers of endocervical cells and/or metaplastic squamous epithelial cells from the transformation zone (EC/TZ) make the specimen unrepresentative; however, the Bethesda classification recommends that the report on the findings must include the information that EC/TZ are lacking.

B) Quality of smear: "Unsatisfactory because..."

(one of the following criteria must be met):

- ...not representative

- smear specimen lacks sufficient number of cells (estimated number for conventional smear: 5000 to 8000 well preserved and clearly visible squamous epithelial cells; estimated number for thin-layer specimens: 2000 to 5000). The number of cells can vary depending on the initial clinical situation (pregnancy, hormone therapy, age, etc.).

- no or too few columnar epithelial cells and/or metaplastic cells present in specimen (irrespective of the woman's age!) from patient's ectocervix (see above for reasons).

- ... only limited assessment possible (method and technical processing, etc.):

- important clinical information is lacking, cf. II/1

- poor fixation

- there is slight to moderate cell damage in the form of smear artifacts (crush artifacts)

- more than 50-75\% of epithelial cell components are obscured by blood, inflammatory cells, thick layer of cells, contamination ( Fig. 9). 


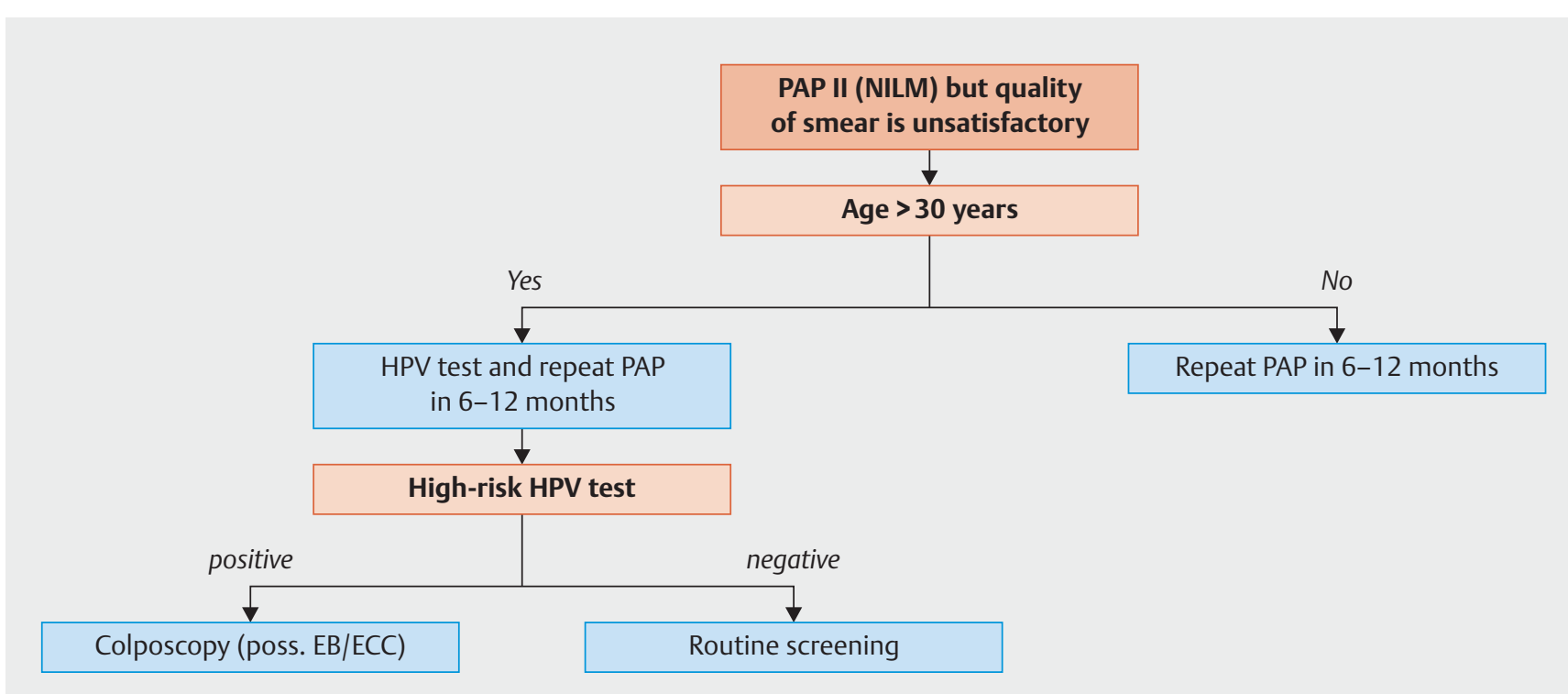

- Fig. 9 PAP II (NILM) but quality of smear is unsatisfactory. [rerif]

C) Quality of smear: “Cannot be assessed” (Pap 0) (one of the following criteria is present)

1. Smear slide cannot be identified or slide cannot be assigned to specific procedure.

- Specimen slide is broken or not present (was not received)

2. Criteria for representativity, method and technical processing:

- Insufficient number of squamous epithelial cells (less than estimated 5000 squamous epithelial cells in conventional smear or less than 2000 squamous epithelial cells in thinlayer specimens)

- Very poor or no fixation; air-drying artifacts

- More than $75 \%$ of epithelial cells obscured by blood, inflammation, thick layer of cells, contamination

- Extensive cell damage due to smear artifacts (crush artifacts)
Note: Data on representativity must be reported for all cases, particularly for PAP I and II. PAP I requires a smear which is representative and can be clearly evaluated. Although it is of secondary importance, reports on cases with PAP III or higher should also include information on the quality of the smear, including whether the smear is representative/can be clearly assessed. The data must be recorded even if the suspicious findings (PAP III or higher) are not representative or insufficiently representative as any such findings must be investigated further without delay.

\subsection{Nomenclature of findings}

Cytological findings must be reported using a mandatory nomenclature und national ( $\vee$ Table 1 ) and international classification. The results, classified according to the Bethesda System, should be included in the report on findings. 
- Table 12018 Austrian gynecological cytology nomenclature and Bethesda equivalent.

\begin{tabular}{|c|c|c|}
\hline PAP group & Reporting of cervical cytology findings & Bethesda 2015 equivalent \\
\hline \multirow[t]{3}{*}{0} & Cannot be assessed & Unsatisfactory for evaluation \\
\hline & $\begin{array}{l}\text { a) Cannot be processed because of technical and/or administrative } \\
\text { deficiencies... (state cause) }\end{array}$ & $\begin{array}{l}\text { a.) Rejected specimen (not processed) } \\
\text { because... (specimen not labelled, slide } \\
\text { broken, etc.) }\end{array}$ \\
\hline & $\begin{array}{l}\text { b) Can be processed - but cannot be assessed because ... (state cause - } \\
\text { cf. criteria for adequacy of smear) }\end{array}$ & $\begin{array}{l}\text { b.) Fully evaluated, unsatisfactory speci- } \\
\text { men: Specimen processed and exam- } \\
\text { ined, but unsatisfactory for evaluation } \\
\text { of epithelial abnormality because of... } \\
\text { (obscuring blood, etc.) }\end{array}$ \\
\hline I & $\begin{array}{l}\text { Normal, age-appropriate cells (including squamous metaplasia), represen- } \\
\text { tative smear which can be clearly assessed; increase in inflammatory cells } \\
\text { without epithelial changes; atrophy without cytolysis in representative } \\
\text { smear specimen. }\end{array}$ & $\begin{array}{l}\text { Negative for intraepithelial lesion } \\
\text { or malignancy (NILM) }\end{array}$ \\
\hline II & $\begin{array}{l}\text { Inflammatory (state organism if possible: fungal, trichomonas vaginalis, } \\
\text { HSV, bacterial flora, etc.); reactive/reparative or degenerative changes; } \\
\text { hyperkeratosis and parakeratosis; tubal metaplasia; pregnancy-related cells; } \\
\text { normal endometrial cells (only if clinical information states that woman is } \\
\text { postmenopausal or aged } \geq 45 \text { years); irradiation-related cell changes; } \\
\text { atrophic cells with cytolysis. } \\
\text { Normal, age-appropriate cells, but quality of smear is unsatisfactory. }\end{array}$ & $\begin{array}{l}\text { Negative for intraepithelial lesion } \\
\text { or malignancy/other (NILM) }\end{array}$ \\
\hline \multirow[t]{2}{*}{ III } & $\begin{array}{l}\text { More pronounced inflammatory-regenerative and/or degenerative and/or } \\
\text { atrophic changes which cannot be definitively classified (SIL or invasive } \\
\text { carcinoma cannot be excluded). }\end{array}$ & $\begin{array}{l}\text { Atypical squamous cells - undetermined } \\
\text { significance (ASC-US) }\end{array}$ \\
\hline & $\begin{array}{l}\text { More pronounced inflammatory-regenerative and/or degenerative and/or } \\
\text { atrophic changes which cannot be definitively classified; atypical immature } \\
\text { metaplasia, HSIL or invasive carcinoma cannot be excluded. }\end{array}$ & $\begin{array}{l}\text { Atypical squamous cells - cannot exclude } \\
\text { a high-grade squamous intraepithelial } \\
\text { lesion (ASC - H) }\end{array}$ \\
\hline IIID & $\begin{array}{l}\text { HPV-associated cell changes (koilocytes, dyskeratotic cells) } \\
\text { Low-grade squamous intraepithelial lesion/neoplasia cells (LSIL). } \\
\text { Optional: corresponds to previous CIN I or low-grade dysplasia classification. }\end{array}$ & $\begin{array}{l}\text { Low grade squamous intraepithelial } \\
\text { lesion (LSIL) }\end{array}$ \\
\hline \multirow[t]{2}{*}{ IIIG } & $\begin{array}{l}\text { Atypical glandular cells (where possible, please specify whether endocervical } \\
\text { or endometrial or cannot be otherwise specified), tendency to proliferate, } \\
\text { reactive. }\end{array}$ & $\begin{array}{l}\text { Atypical endocervical or endometrial } \\
\text { or glandular cells (NOS or specify in } \\
\text { comment) (AGC) }\end{array}$ \\
\hline & $\begin{array}{l}\text { Atypical glandular cells (where possible, please specify whether endocervical } \\
\text { or endometrial) suspicious for neoplastic changes. }\end{array}$ & $\begin{array}{l}\text { Atypical endocervical or glandular cells, } \\
\text { favor neoplastic (AGC) }\end{array}$ \\
\hline \multirow[t]{2}{*}{ IV } & $\begin{array}{l}\text { High-grade squamous intraepithelial lesion/neoplasia cells (HSIL). } \\
\text { Optional: corresponds to previous CIN II/III or moderate to high-grade dysplasia } \\
\text { classification. }\end{array}$ & $\begin{array}{l}\text { High grade squamous intraepithelial } \\
\text { lesion (HSIL) }\end{array}$ \\
\hline & Cells of endocervical adenocarcinoma in situ (AIS). & $\begin{array}{l}\text { Endocervical adenocarcinoma in situ } \\
\text { (AIS) }\end{array}$ \\
\hline \multirow[t]{3}{*}{ v } & Cells of (presumably) invasive squamous cell carcinoma. & Squamous cell carcinoma \\
\hline & $\begin{array}{l}\text { Adenocarcinoma cells (please specify where possible: endocervical or } \\
\text { endometrial or extrauterine). }\end{array}$ & $\begin{array}{l}\text { Adenocarcinoma (endocervical, } \\
\text { endometrial, extrauterine, NOS) }\end{array}$ \\
\hline & $\begin{array}{l}\text { Cells from other malignant tumors (please state tumor cell type, using the } \\
\text { current WHO classification where possible). }\end{array}$ & Other malignant neoplasms (specify) \\
\hline
\end{tabular}




\section{Conflict of Interest}

See Table 2 .

Table 2 Potential conflicts of interest of authors.

Reich O. $\quad$ Consultancy services or expert opinions: no; honoraria, speaker's and training fees: yes - Hologic, Roche, Sanofi Pasteur; financial benefits (external grants): yes - MSD; ownership interests: no; shareholder interests: no

Braune G. Consultancy services or expert opinions: no; honoraria, speaker's and training fees: no; financial benefits (external grants): no; ownership interests: no; shareholder interests: no

Eppel W. $\quad$ Consultancy services or expert opinions: no; honoraria, speaker's and training fees: no; financial benefits (external grants): no; ownership interests: no; shareholder interests: no

Fiedler T. Consultancy services or expert opinions: yes - MSD, Roche; honoraria, speaker's and training fees: no; financial benefits (external grants): no; ownership interests: no; shareholder interests: no

Graf A. Consultancy services or expert opinions: no; honoraria, speaker's and training fees: no; financial benefits (external grants): no; ownership interests: no; shareholder interests: no

Hefler L.

Consultancy services or expert opinions: yes - PharmaMar, Roche, Tesaro, AstraZeneca; honoraria, speaker's and training fees: yes - PharmaMar, Roche, Tesaro; financial benefits (external grants): yes - PharmaMar, Roche, Tesaro, AstraZeneca, ownership interests: no; shareholder interests: no

Joura E.

Consultancy services or expert opinions: yes - MSD, Roche; honoraria, speaker's and training fees: yes - MSD, Roche; financial benefits (external grants): no; ownership interests: no; shareholder interests: no

Kölbl H. Consultancy services or expert opinions: no; honoraria, speaker's and training fees: no; financial benefits (external grants): no; ownership interests: no; shareholder interests: no

Marth C. Consultancy services or expert opinions: yes - Roche, Novartis, Amgen, MSD, AstraZeneca, Pfizer, PharmaMar, Cerulean, Vertex, Tesaro; honoraria, speaker's and training fees: yes - Roche, Novartis, Amgen, MSD, AstraZeneca, PharmaMar, Tesaro; financial benefits (external grants): yes - EU, FWF, AstraZeneca, Roche; ownership interests: no; shareholder interests: no

Pokieser W. Consultancy services or expert opinions: no; honoraria, speaker's and training fees: no; financial benefits (external grants): yes - from the external funding account of the Institute for Pathology; ownership interests: no; shareholder interests: no

Regitnig P. Consultancy services or expert opinions: no; honoraria, speaker's and training fees: yes - Roche, AstraZeneca; financial benefits (external grants): no; ownership interests: no; shareholder interests: no

Reinthaller A. Consultancy services or expert opinions: no; honoraria, speaker's and training fees: yes - Amgen, AstraZeneca, Novartis, Roche, Roche Diagnostics, Tesaro; financial benefits (external grants): yes - AstraZeneca, Roche; ownership interests: no; shareholder interests: no

Tamussino K. Consultancy services or expert opinions: no; honoraria, speaker's and training fees: no; financial benefits (external grants): no; ownership interests: no; shareholder interests: no

Widschwendter A. Consultancy services or expert opinions: no; honoraria, speaker's and training fees: yes; financial benefits (external grants): no; ownership interests: no; shareholder interests: no

Zeimet $\mathrm{A}$. Consultancy services or expert opinions: yes - Roche, Amgen AstraZeneca, PharmaMar, Tesaro; honoraria, speaker's and training fees: yes - Roche, Amgen AstraZeneca, PharmaMar, Tesaro; financial benefits (external grants): no; ownership interests: no; shareholder interests: no

Kohlberger P. Consultancy services or expert opinions: no; honoraria, speaker’s and training fees: no; financial benefits (external grants): no; ownership interests: no; shareholder interests: no 


\section{References}

[1] Arbyn M, Snijders PJ, Meijer CJ et al. Which high-risk HPV assays fulfil criteria for use in primary cervical cancer screening? Clin Microbiol Infect 2015; 21: 817-826

[2] Arbyn M, Redman CWE, Verdoodt F et al. Incomplete excision of cervical precancer as a predictor of treatment failure: a systematic review and meta-analysis. Lancet Oncol 2017; 18: 1665-1679

[3] Arbyn M, Anttila A, Jordan J et al. European Guidelines for Quality Assurance in Cervical Cancer Screening. 2nd ed. European Commission; 2008

[4] Bornstein J, Bentley J, Bösze P et al. 2011 colposcopic terminology of the International Federation for Cervical Pathology and Colposcopy. Obstet Gynecol 2012; 120: 166-172

[5] Bosch FX, Lorincz A, Munoz N et al. The causal relation between human papillomavirus and cervical cancer. J Clin Pathol 2002; 55: 244-265

[6] Girardi F, Frey Tirri B, Küppers $V$ et al. Neue kolposkopische IFCPC-Nomenklatur der Cervix uteri (Rio de Janeiro 2011), Approbierte Darstellung und Erläuterung für Deutschland, Österreich und die deutschsprachige Schweiz. Frauenarzt 2012; 53: 1064-1066

[7] Gosvig CF, Huusom LD, Andersen KK et al. Long-term follow-up of the risk for cervical intraepithelial neoplasia grade 2 or worse in HPV-negative women after conization. Int J Cancer 2015; 137: 2927-2933

[8] Holl K, Nowakowski AM, Powell $\mathrm{N}$ et al. Human papillomavirus prevalence and type-distribution in cervical glandular neoplasias: Results from a European multinational epidemiological study. Int J Cancer 2015; 137 : 2858-2868

[9] Joura EA, Garland SM, Paavonen J et al.; FUTURE I and II Study Group. Effect of the human papillomavirus (HPV) quadrivalent vaccine in a subgroup of women with cervical and vulvar disease: retrospective pooled analysis of trial data. BMJ 2012; 344: 1401

[10] Joura EA, Giuliano AR, Iversen OE et al.; Broad Spectrum HPV Vaccine Study. A 9-valent HPV vaccine against infection and intraepithelial neoplasia in women. NEJM 2015; 372: 711-723

[11] Kang WD, Choi HS, Kim SM. Is vaccination with quadrivalent HPV vaccine after loop electrosurgical excision procedure effective in preventing recurrence in patients with high-grade cervical intraepithelial neoplasia (CIN2-3)? Gynecol Oncol 2013; 130: 264-268

[12] Kjaer SK, Frederiksen K, Munk C et al. Long-term absolute risk of cervical intraepithelial neoplasia Grade 3 or worse following human papillomavirus infection: role of persistence. J Natl Cancer Inst 2010; 102: $1478-1488$

[13] Kurman RJ, Carcangiu ML, Herrington S et al. WHO Classification of Tumours of Female Reproductive Organs. Lyon: IARC Press; 2014
[14] Kyrgiou M, Athanasiou A, Paraskevaidi M et al. Adverse obstetric outcomes after local treatment for cervical preinvasive and early invasive disease according to cone depth: systematic review and meta-analysis. BMJ 2016; 354: 3633

[15] Meijer C], Berkhof J, Castle PE et al. Guidelines for human papillomavirus DNA test requirements for primary cervical cancer screening in women 30 years and older. Int J Cancer 2009; 124: 516-520

[16] Moss EL, Arbyn M, Dollery E et al. European Federation of Colposcopy quality standards Delphi consultation. Eur ] Obstet Gynecol Reprod Biol 2013; 170: 255-258

[17] Massad LS, Einstein MH, Huh WK et al. 2012 updated consensus guidelines for the management of abnormal cervical cancer screening tests and cancer precursors. Obstet Gynecol 2013; 121: 829-846

[18] Nayar R, Wilbur BC. The Bethesda System: The Bethesda System for Reporting Cervical Cytology. 3rd ed. Springer; 2015

[19] Braune G, Fiedler T, Hefler L et al. OEGGG Positionspapier HPV. Online: https://www.oeggg.at/leitlinien-stellungnahmen/gynäkologie-1/; last access: 27.09.2018

[20] Quaas ], Reich O, Frey Tirri B et al. Explanation and use of the Colposcopy Terminology of the IFCPC (International Federation for Cervical Pathology and Colposcopy) Rio 2011. Geburtsh Frauenheilk 2013; 73: 904-907

[21] Regitnig P. Die neue Nomenklatur der ÖGZ und ÖGPath/IAP Austria mit Erläuterungen. Spectrum Pathologie 2017; 1: 7-9

[22] Reich O, Lahousen M, Pickel $\mathrm{H}$ et al. Cervical intraepithelial neoplasia III: long-term follow-up after cold-knife conization with involved margins. Obstet Gynecol 2002; 99: 193-196

[23] Reich O, Regauer S, Marth C et al. Precancerous Lesions of the Cervix, Vulva and Vagina According to the 2014 WHO Classification of Tumors of the Female Genital Tract. Geburtsh Frauenheilk 2015; 75: 1018-1020

[24] Leitlinienprogramm Onkologie (Deutsche Krebsgesellschaft, Deutsche Krebshilfe, AWMF). S3-Leitlinie Prävention des Zervixkarzinoms; Langversion 1.0 - Dezember 2017; AWMF-Registernummer 015/027OL. Online: http://www.leitlinienprogramm-onkologie.de/leitlinien/ zervixkarzinom-praevention/; last access: 27.09.2018

[25] Stoler MH, Castle PE, Solomon D; American Society for Colposcopy and Cervical Pathology. The expanded use of HPV testing in gynecologic practice per ASCCP-guided management requires the use of well-validated assays. Am J Clin Pathol 2007; 127: 335-357

[26] Tainio K, Athanasiou A, Tikkinen KAO et al. Clinical course of untreated cervical intraepithelial neoplasia grade 2 under active surveillance: systematic review and meta-analysis. BMJ 2018; 360: 499

[27] Walboomers JM, Jacobs MV, Manos MM et al. Human papillomavirus is a necessary cause of invasive cervical cancer worldwide. J Pathol 1999; 189: $12-19$

[28] Wentzensen N, Walker JL, Gold MA et al. Multiple biopsies and detection of cervical cancer precursors at colposcopy. J Clin Oncol 2015; 33: 83-89 


\section{Guideline Program}

\section{Editors}

Leading Professional Medical Associations

\section{OT}

\section{OEGGE}

\section{German Society of Gynecology and Obstetrics} (Deutsche Gesellschaft für Gynäkologie und Geburtshilfe e. V. [DGGG])

Head Office of DGGG and Professional Societies Hausvogteiplatz 12, DE-10117 Berlin info@dggg.de

http://www.dggg.de/

\section{President of DGGG}

Prof. Dr. med. Anton Scharl

Direktor der Frauenkliniken

Klinikum St. Marien Amberg

Mariahilfbergweg 7, DE-92224 Amberg

Kliniken Nordoberpfalz AG

Söllnerstraße 16, DE-92637 Weiden

\section{DGGG Guidelines Representatives}

Prof. Dr. med. Matthias W. Beckmann Universitätsklinikum Erlangen, Frauenklinik Universitätsstraße 21-23, DE-91054 Erlangen

Prof. Dr. med. Erich-Franz Solomayer Universitätsklinikum des Saarlandes Geburtshilfe und Reproduktionsmedizin

Kirrberger Straße, Gebäude 9, DE-66421 Homburg

\section{Guidelines Coordination}

Dr. med. Paul Gaß, Dr. med. Gregor Olmes, Christina Meixner Universitätsklinikum Erlangen, Frauenklinik Universitätsstraße 21-23, DE-91054 Erlangen fk-dggg-leitlinien@uk-erlangen.de http://www.dggg.de/leitlinienstellungnahmen
Austrian Society of Gynecology and Obstetrics (Österreichische Gesellschaft für Gynäkologie und Geburtshilfe [OEGGG])

Frankgasse 8, AT-1090 Wien stephanie.leutgeb@oeggg.at http://www.oeggg.at

\section{President of OEGGG}

Prof. Dr. med. Petra Kohlberger

Universitätsklinik für Frauenheilkunde Wien

Währinger Gürtel 18-20, AT-1090 Wien

\section{OEGGG Guidelines Representatives}

Prof. Dr. med. Karl Tamussino

Universitätsklinik für Frauenheilkunde und Geburtshilfe Graz Auenbruggerplatz 14, AT-8036 Graz

Prof. Dr. med. Hanns Helmer Universitätsklinik für Frauenheilkunde Wien Währinger Gürtel 18-20, AT-1090 Wien

\section{gynécologie}

Swiss Society of Gynecology and Obstetrics (Schweizerische Gesellschaft für Gynäkologie und Geburtshilfe [SGGG])

Gynécologie Suisse SGGG Altenbergstraße 29, Postfach 6, CH-3000 Bern 8

sekretariat@sggg.ch

http://www.sggg.ch/

\section{President of SGGG}

Dr. med. David Ehm

FMH für Geburtshilfe und Gynäkologie Nägeligasse 13, CH-3011 Bern

SGGG Guidelines Representatives

Prof. Dr. med. Daniel Surbek

Universitätsklinik für Frauenheilkunde

Geburtshilfe und feto-maternale Medizin

Inselspital Bern

Effingerstraße 102, CH-3010 Bern

Prof. Dr. med. René Hornung

Kantonsspital St. Gallen, Frauenklinik

Rorschacher Straße 95, CH-9007 St. Gallen 